\title{
Using Self-Regulated Learning to Promote Students' Metacognitive Awareness in Learning Electricity
}

\author{
Miftah Bahari ${ }^{1}$, Ari Widodo ${ }^{2}$, Nanang Winarno ${ }^{3}$ \\ \{dita.khairina@yahoo.com ${ }^{1}$, widodo@upi.edu ${ }^{2}$, nanang_winarno@upi.edu ${ }^{3}$ \} \\ Department of Science Education, Universitas Pendidikan Indonesia ${ }^{1}$ \\ Department of Biology Education, Universitas Pendidikan Indonesia ${ }^{2}$ \\ Department of Mathematics Education, Universitas Pendidikan Indonesia ${ }^{3}$
}

\begin{abstract}
Metacognitive awareness is an important aspect to develop as it possibly compensates low ability in concept mastery or lack of relevant prior knowledge. This study aims to investigate the effect of self-regulated learning on students' metacognitive awareness. The method used is a weak experiment method. The sample includes 27 students consisting of 14 females and 13 males from junior high school in Bandung. Selfregulated learning is also found to have $\mathrm{N}$-gain value of 0.19 meaning that there is a low improvement in students' metacognitive awareness. The treatment improves the domain of procedural knowledge the highest out of eight aspects in metacognitive awareness. This research shows that the difference in the result of the application of self-regulated learning in different gender results in higher metacognitive awareness in female students. This research will be beneficial for researchers by providing them further materials and data on how self-regulated learning affects students' metacognitive awareness.
\end{abstract}

Keywords: Self-Regulated Learning, Metacognitive Awareness, Electricity

\section{Introduction}

Teachers have troubles in managing their time and delivered materials because of how tight the schedule in lessons are, they also have trouble in keeping the students active as students' is required to study independently [1-2]. The topic of electricity is decided to be the main topic of investigation in this research because even students that are already learning electricity very thoroughly that have a very lacking basic concept of electricity and magnetism (E and M) [3]. Reports on the learning of electricity such as) indicate that electricity is one of the most recalcitrant or troubling topics for many senior school students [4]. Physics in general also induce the same response as it is seen to be very difficult and that many students do not have strong prior knowledge which causes them to mistaken lots of basic concepts.

An aspect that students' is shown to be lacking is their metacognitive awareness as to why it is selected as another dependent variable in this research. This aspect is very important for students to be developed in general, it is expected for metacognitive knowledge and regulation to improve as the mastery or expertise on a particular domain also improves [5]. Metacognitive awareness or knowledge can make up for Intelligence Quotient (IQ) [6]. A study pronounced two very crucial findings which are: (1) metacognitive awareness is not strongly related or correlated to students' ability (although there is a subtle positive correlation between the two) [7], (2) metacognitive awareness or knowledge is involved in successful 
problem solving regardless of the IQ of the students or the strategies they use. Thus, the solution that can be suggested to be investigated is self-regulated learning as it is that one of the strategies of learning that is found to be deeply supportive of the student-centered environment is self-regulated learning [8]. Although students show signs in class as if they understand the basic theory of electricity thoroughly, it is often mixed with a lot of misunderstanding which is why a way for them to organize and manage their learning on their own is needed.

Previously there are already several similar pieces of research that have investigated on regulated learning, academic achievement and metacognitive awareness [9] that researches on metacognitive awareness and goal setting as a part of self-regulated learning to improve academic performance [10]. The reciprocal relationship between self-regulated learning and metacognitive awareness towards academic achievement in writing has also been researched [11-13]. Further roles of metacognition in self-regulated learning itself have been investigated as well as research that conducted a survey that indicates a correlation between self-regulated learning and metacognition [14]. Another study researched online application of metacognitive and cognitive strategy to improve both self-regulated learning and academic achievement [15].

However, different to previous researches, this research initiates to investigate on the effect of self-regulated learning in the topic of electricity and uses self-regulated learning as the variable that is being implemented by using a journal instead of being measured. This research also further discusses the effect of self-regulated learning on each aspect of metacognitive awareness and gender differences in the application of self-regulated learning. This study is beneficial for teachers by providing teachers with an understanding of how students learn is also beneficial for students by providing them with information of whether or not self-regulated learning is a strategy of learning effective enough. This study is beneficial for researchers by providing them further materials and data on how self-regulated learning affects students' metacognition. This study aims to determine the effect of self-regulated learning on students' metacognition on the topic of electricity.

\section{Research Method}

The research method applied in this study is weak experiment method [16]. The research also uses pre-test post-test design as shown in Table 1. The sampling method used is convenience sampling. The chosen school uses the Cambridge Curriculum. 27 students of 7 graders that come from School $\mathrm{X}$ is used as the sample. There are 13 male students who are $48.1 \%$ of the sample, and there are 14 females' students which are $51.9 \%$ of the sample. The age group of the sample is 11-12 years old.

The instrument used is a Metacognitive Awareness Inventory (MAI) [17] that has been tested on validity and reliability as the questionnaire has not been changed as based on expert judgment with 52 questions, the questionnaire is suitable for Indonesian Junior High School students as it is. The questionnaire only includes two choices of options, "True" or "False". A "True" is valued as one mark and a "False" is valued as zero marks. Research on problems in science learning and the variables are first conducted, the instrument is then made and searched for and judged for its reliability and validity with both expert judgment from two lecturers with the basic of science education and the teacher that is in the sampled school. Data is collected in two weeks treatment of self-regulated learning. Self-regulated learning is a 
learning strategy that is applied by the use of a booklet that applies three stages of selfregulated learning of forethought, performance and self-reflection. The material of electrical components and resistance is taught in one lesson and they are to fill in their booklet of the taught subject in a week and to be checked in the next week. As there are only three main subtopics of electricity taught, it only requires two weeks for the research to be applied on them. The data will be analyzed based on the percentages, and the n-gain per-aspects as well as the difference between different genders.

Table 1. Research Design.

\begin{tabular}{ccc}
\hline $\mathrm{O}$ & $\mathrm{X}$ & $\mathrm{O}$ \\
\hline Pre-test & Treatment & Post-test \\
\hline
\end{tabular}

\section{Result and Discussion}

Students' metacognitive awareness is assessed by giving all participants a questionnaire [17] called Metacognitive Awareness Inventory (MAI) as pre-test and post-test of the implementation of self-regulated learning consisting of 52 questions. As shown in Table 2, according to the hypothesis statements and the result of Paired Sample T-test hypothesis test, it can be concluded that there is a significant difference in students' metacognitive awareness after the implementation of self-regulated learning.

In addition to the conclusion of there is a significant difference between the result of pretest and post-test, the normalized gain shows the increase of students' metacognitive awareness by the implementation of self-regulated learning experienced by the participants as a low improvement [18]. According to the hypothesis statements and the result of paired sample T-test, it can be concluded that there is a difference in students' academic achievement in learning electricity after the implementation of self-regulated learning as $\mathrm{H}_{0}$ is rejected and $\mathrm{H}_{1}$ is retained [9-11, 13-14, 19-22]. The journal itself as a form of media of self-regulated learning may play a part in the improvement of the metacognition. [23] A lot of findings clearly indicate the use of direct instructions from the teacher, peer-teaching, as well as selfreflection supported in small group discussions and journals can be used as a tool to develop students' metacognitive knowledge and strategies management. Of course, all the different tools will improve different aspects of metacognitive knowledge and regulation and therefore should be used in an integrated manner [24]. 
Table 2. Statistic Results of self-regulated learning on metacognitive awareness

\begin{tabular}{cc}
\hline Component & Metacognitive Awareness \\
\hline Gain & 7.55 \\
N-gain & 0.19 \\
Category & Low \\
\hline & Hypothesis Test \\
\hline Asymp.Sig $(<0.05)$ & Paired Sample T-test \\
Information & 0.000 \\
Conclusion & $\mathrm{H}_{0}$ is rejected \\
\hline
\end{tabular}

The low of improvement may also be caused by the lack of control in the environment in which the self-regulated learning was implemented. Students were not introduced to various strategies that they can implement thoroughly which results in the lack of strategizing for their learning on their own. [13] Control of the environment is one of the most important steps for students in order to protect their learning in school. Engaging them in various strategies while assuming that their metacognitive awareness will be triggered.

\subsection{The Effect of Self-Regulated Learning on Students' Metacognitive Awareness per- Subscales}

There is two medium improvements students' metacognitive awareness which is in the subscale procedural knowledge and comprehension monitoring. The reason as to why these two are the subscales that improve the most will be further discussed in the subdivisions. There is the only slight difference in the n-gain of both pieces of knowledge of cognition and regulation of cognition. This slight difference might be explained [5] by the statement that there are two important main points regarding knowledge and regulation of cognition. The first thing that he mentioned is that both of them is related to each other. [6] An example of this relationship explains how declarative knowledge of cognition could help in the regulation of problem-solving in students of fifth and sixth graders. Research in the previous years [17] also supports the idea by reporting how college students' ability to judge their ability of comprehension monitoring were significantly related to their observed monitoring accuracy as well as performance in tests. [25] Knowledge of strategies is significantly related to selfreported strategy used. [26] Another research also supports the idea.

In another research, it states that metacognitive knowledge and regulation are developed much earlier in gifted students compared to non-gifted students [23]. A study [27] also proves the same point where they have reportedly found that fifth and sixth graders that are gifted, scores higher on planning and metacognitive knowledge compared to non-gifted students. The same result is also reported in another research [24] with students from the eighth grades, gifted students are found to use more strategies, higher monitoring accuracy and put in more effort in comparison to non-gifted students. [23] also stated that different variation of instructions will broaden the level of metacognition. Students may not only develop one knowledge but also several regulation skills of cognition, Students may develop conditional knowledge together with planning and evaluation skills. There are several guidelines as to how to improve monitoring as well as evaluation skills [28] however these researches promote more of a teacher and peer monitoring as well as discussion on several possible strategies 
used. Preliminary evidence has supported that between these two general components, they are intercorrelated in around $\mathrm{r}=0.50$ range.

3.1.1 Knowledge of Cognition. The component of metacognitive knowledge includes three subdivisions of metacognitive awareness, they are declarative knowledge, procedural knowledge, and conditional knowledge [23]. Procedural knowledge has the highest improvement in comparison to all of the other aspects in the knowledge of cognition as shown in Figure 1. The reason as to why procedural knowledge improves the most is due to procedural knowledge always broadly defined as knowledge or cognitive activity that regulates any aspect of the cognitive activity [29-30].

However, [31] metacognitive knowledge is neither stable or conscious action. Children for example often shows and use their knowledge of cognition without understanding what that knowledge is [32]. Even adults have problems with detailing their own expert cognition and describe their own use of cognition [33]. The finding of a recent study that demonstrates the development between the early theory of mind and declarative metacognitive knowledge, especially in the language competencies [30]. [Metacognitive knowledge can also compensate for students with lower achievement or lack in prior knowledge. [6] Metacognitive knowledge can compensate for a student with low Intelligence Quotient (IQ). Students with high metacognition are found to use fewer strategies but can solve problems more effectively.

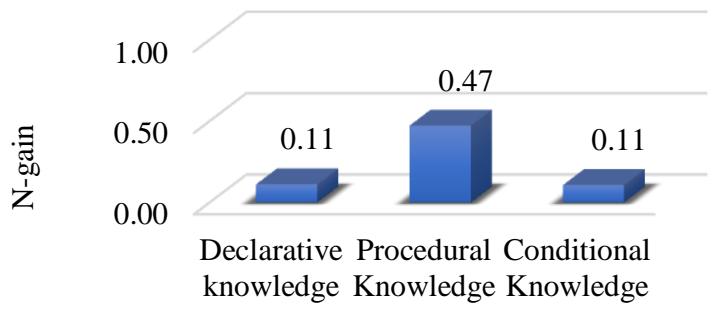

Fig. 1. Knowledge of cognition.

3.1.2 Regulation of Cognition. [5] The regulation of cognition is defined as a set of activities that helps students to control their own learning. Researches support that there is an assumption that metacognitive regulation will improve students' performance in various ways such as better use of resources, use of existing strategies and awareness of their own comprehension. A lot of studies have reported significant improvements in students' learning after the use of regulatory skills and understand the use of these skills in the integrated classroom instructions [34]. These studies indicate that even younger students may be able to use metacognitive skills by using direct instructions, the main three essential skills are planning, monitoring and evaluation [35].

This finding suggests that as students go further in their learning, they will not only achieve metacognitive knowledge but also how to use that knowledge in a more adaptive manner in different areas of learning. As shown in Figure 2, the highest improvement in the components of regulation in cognition is in the comprehension monitoring, there is also a 
noticeable improvement in information management strategies and evaluation, with planning having the least improvement out of all the components in the regulation of cognition.

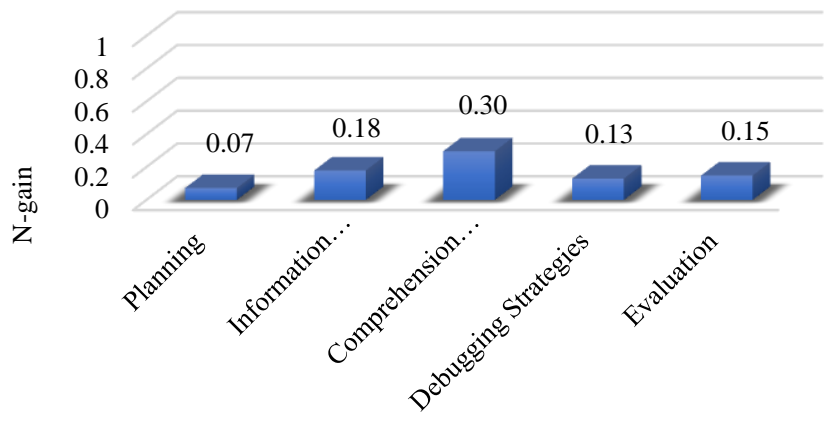

Fig. 2. Regulation of cognition.

\subsection{The Effect of Self-Regulated Learning on Students' Metacognitive Awareness per- Gender}

There is a difference between female and male students' metacognition both before and after the treatment. The result shows that females have better metacognitive awareness before and after the treatment of self-regulated learning. This result is in line with several types of research. According to [36], girls are reportedly using more metacognitive strategy in comparison to boys and they also often score higher in comprehension monitoring [37]. However, a lot of studies have suggested that although girls have higher scores in metacognition than boys, the difference is not that big and often said as not statistically significant [38]. Another research [39] states that there are some gender differences in metacognition. The most differences are found on knowledge of cognition rather than on regulation of cognition. However, some elements of both knowledge and regulation of cognition are differently related to learning according to pupils' gender. It seems that males and females use different metacognitive knowledge and regulation skills in learning. Contradictory to the result of this research, however, there is another study found that there is consistency from the 21 years before 1995 in different researches regarding the difference in a positive attitude towards Science from both sexes which proves against this result. A more positive attitude is shown by the males towards Science [40 - 41]. A recent study also supports this finding on the statement that Science is taken more positively by boys as they express higher level of self-efficacy, interest, and enjoyment in general in comparison to females especially in countries that have less bias towards gender [42].

\section{Conclusion}

The implementation of self-regulated learning can also improve students' metacognitive awareness. It can be proven by $\mathrm{N}$-gain result that shows there is low improvement between the pre-test and post-test of the treatment. The average $\mathrm{N}$-gain of the experiment is 0.19 . In addition, from the hypothesis test, it is proven that the hypothesis $\mathrm{H} 1$ is accepted, meaning that there is a significant difference between the pre-test and post-test. This means, there is a 
significant improvement in students' academic achievement through the application of selfregulated learning. The first recommendation is that it is necessary to implement the treatment for a long time as it takes time for students to get used to the treatment. The second recommendation would be for the teacher to understand thoroughly what students need and instructions that help students to apply the best self-regulated learning. The third recommendation is to include variation of samples instead of just higher-achieving class or low achieving class. The fourth recommendation is to investigate the application of selfregulated learning in other subjects and factors.

\section{References}

[1] Retnawati, H.: Hambatan guru matematika sekolah menengah pertama dalam menerapkan kurikulum baru. Jurnal Cakrawala Pendidikan, 34(3), (2015)

[2] Ariyanti, D., \& Kuswanto, H.: Evaluasi guru dalam pembelajaran sains pada implementasi kurikulum 2013. In PROSIDING: Seminar Nasional Fisika dan Pendidikan Fisika, 5 (3), (2014)

[3] Finkelstein, N.: Learning physics in context: A study of student learning about electricity and magnetism. International Journal of Science Education, 27(10), 1187-1209, (2005)

[4] Shipstone, D. M.: A study of children's understanding of electricity in simple DC circuits. European journal of science education, 6(2), 185-198, (1984)

[5] Schraw, G.: Promoting general metacognitive awareness. Instructional Science, 26(1-2), 113-125, (1998)

[6] Swanson, H. L.: Influence of metacognitive knowledge and aptitude on problem-solving. Journal of educational psychology, 82(2), 306, (1990)

[7] Alexander, J. M., Carr, M., \& Schwanenflugel, P. J.: Development of metacognition in gifted children: Directions for future research. Developmental Review, 15(1), 1-37, (1995)

[8] Azevedo, R., Behnagh, R., Duffy, M., Harley, J., \& Trevors, G.: Metacognition and self-regulated learning in student-centered learning environments. Theoretical foundations of student-centered learning environments, 171-197, (2012)

[9] Ridley, D. S., Schutz, P. A., Glanz, R. S., \& Weinstein, C. E.: Self-regulated learning: The interactive influence of metacognitive awareness and goal-setting. The journal of experimental education, 60(4), 293-306, (1992)

[10] Negretti, R.: Metacognition in student academic writing: A longitudinal study of metacognitive awareness and its relation to task perception, self-regulation, and evaluation of performance. Written Communication, 29(2), 142-179, (2012)

[11] Boekaerts, M.: Self-regulated learning: Where we are today. International journal of educational research, 31(6), 445-457, (1999)

[12] Dinsmore, D. L., Alexander, P. A., \& Loughlin, S. M.: Focusing the conceptual lens on metacognition, self-regulation, and self-regulated learning. Educational psychology review, 20(4), 391-409, (2008)

[13] Corno, L.: The metacognitive control components of self-regulated learning. Contemporary educational psychology, 11(4), 333-346, (1986)

[14] Sperling, R. A., Howard, B. C., Staley, R., \& DuBois, N.: Metacognition and self-regulated learning constructs. educational research and evaluation, 10(2), 117-139, (2004)

[15] Sperling, R. A., Howard, B. C., Staley, R., \& DuBois, N.: Metacognition and self-regulated learning constructs. educational research and evaluation, 10(2), 117-139, (2004)

[16] Fraenkel, J. R., Wallen, N. E., \& Hyun, H. H.: How to design and evaluate research in education. New York: McGraw-Hill Humanities/Social Sciences/Languages, (2011)

[17] Schraw, G., \& Dennison, R. S.: Assessing metacognitive awareness. Contemporary educational psychology, 19(4), 460-475, (1994) 
[18] Hake, R. R.: Interactive-engagement versus traditional methods: A six-thousand-student survey of mechanics test data for introductory physics courses. American Journal of Physics, 66(1), 64-74. (1998)

[19] Hammann, L. A., \& Stevens, R. J.: Metacognitive Awareness Assessment in Self-Regulated Learning and Performance Measures in an Introductory Educational Psychology Course. (1998)

[20] Kauffman, D. F.: Self-regulated learning in web-based environments: Instructional tools designed to facilitate cognitive strategy use, metacognitive processing, and motivational beliefs. Journal of educational computing research, 30(1-2), 139-161. (2004)

[21] McCombs, B. L., \& Marzano, R. J.: Putting the self in self-regulated learning: The self as an agent in integrating will and skill. Educational psychologist, 25(1), 51-69. (1990)

[22] Turan, S., Demirel, Ö., \& Sayek, İ.: Metacognitive awareness and self-regulated learning skills of medical students in different medical curricula. Medical teacher, 31(10), 477-483. (2009)

[23] Schraw, G., \& Graham, T.: Helping gifted students develop metacognitive awareness. Roeper Review, 20(1), 4-8. (1997)

[24] Bouffard-Bouchard, T., Parent, S., \& Lavirée, S.: Self-regulation on a concept-formation task among average and gifted students. Journal of Experimental Child Psychology, 56(1), 115-134. (1993)

[25] Pintrich, P. R., \& De Groot, E. V.: Motivational and self-regulated learning components of classroom academic performance. Journal of educational psychology, 82(1), 33. (1990)

[26] Schraw, G., Horn, C., Thorndike-Christ, T., \& Bruning, R.: Academic goal orientations and student classroom achievement. Contemporary Educational Psychology, 20(3), 359-368. (1995)

[27] Schofield, N. J., \& Ashman, A. F.: The cognitive processing of gifted, high average, and low average ability students. British Journal of Educational Psychology, 57(1), 9-20. (1987)

[28] Swartz, R. J., \& Perkins, D. N.: Teaching thinking: Issues and approaches. Routledge. (2016)

[29] Flavell, J., Wellman, H. M., Kail, R. V., \& Hagen, J. W.: Metamemory; Perspective on the development of memory and cognition. (1977)

[30] Schneider, W., \& Lockl, K.: Procedural metacognition in children: Evidence for developmental trends. Handbook of metamemory and memory, 14, 391-409. (2008)

[31] Butler, D. L., \& Winne, P. H.: Feedback and self-regulated learning: A theoretical synthesis. Review of educational research, 65(3), 245-281. (1995)

[32] Karmiloff-Smith, B. A.: Beyond modularity: A developmental perspective on cognitive science. European journal of disorders of communication, 29(1), 95-105. (1994)

[33] Scardamalia, M., \& Bereiter, C.: Technologies for knowledge-building discourse. Communications of the ACM, 36(5), 37-41. (1993)

[34] Cross, D. R., \& Paris, S. G.: Developmental and instructional analyses of children's metacognition and reading comprehension. Journal of educational psychology, 80(2), 131. (1988)

[35] Jacobs, J. E., \& Paris, S. G.: Children's metacognition about reading: Issues in definition, measurement, and instruction. Educational psychologist, 22(3-4), 255-278. (1987)

[36] Wu, J. Y.: Gender differences in online reading engagement, metacognitive strategies, navigation skills and reading literacy. Journal of Computer Assisted Learning, 30(3), 252-271. (2014)

[37] Kolić-Vehovec, S., \& Bajšanski, I.: Metacognitive strategies and reading comprehension in elementary-school students. European Journal of Psychology of Education, 21(4), 439. (2006)

[38] Roeschl-Heils, A., Schneider, W., \& van Kraayenoord, C. E.: Reading, metacognition and motivation: A follow-up study of German students in grades 7 and 8. European journal of psychology of education, 18(1), 75-86. (2003)

[39] Liliana, C., \& Lavinia, H.: Gender differences in metacognitive skills. A study of the 8th-grade pupils in Romania. Procedia-Social and Behavioral Sciences, 29, 396-401. (2011)

[40] Weinburgh, M.: Gender differences in student attitudes toward science: A meta-analysis of the literature from 1970 to 1991. Journal of Research in Science Teaching, 32(4), 387-398. (1995)

[41] Breakwell, G. M., \& Beardsell, S.: Gender, parental and peer influences upon science attitudes and activities. Public Understanding of Science. (2016)

[42] Stoet, G., \& Geary, D. C.: The gender-equality paradox in science, technology, engineering, and mathematics education. Psychological science, 29(4), 581-593. (2018) 